\title{
THE USE OF A KARSTIC CAVE SYSTEM IN A STUDY OF ACTIVE TECTONICS: FAULT MOVEMENTS RECORDED AT DRINY CAVE, MALÉ KARPATY MTS (SLOVAKIA)
}

\author{
Miloš Briestenskí1*, Josef Stemberk¹, Jozef Michalík², Pavel Bella³, and Matt Rowberry ${ }^{1}$
}

\begin{abstract}
This paper reports on a study of active tectonics undertaken in the intracratonic setting of central Europe in the junction zone between Eastern Alps and Western Carpathians. The study site is focused on the karstic system of Driny Cave in the Malé Karpaty Mts, Slovakia. A range of geological, geomorphological, and in situ displacement data are presented. From previous geological mapping and our slickenside analyses, it is clear that the cave system has developed along significant fault structures. Further geomorphological investigations pointed towards ongoing faulting and block movements. For example, a number of slope failures can be seen on the hillsides above the cave and numerous fresh speleothem breaks can be observed within the cave. To test this hypothesis, three optical-mechanical crack gauges were installed in 2005. These gauges confirmed and quantified the ongoing movements. The NNE-SSW striking fault has recorded a strike-slip trend of $0.1 \mathrm{~mm} /$ year and a normal fault trend of $0.03 \mathrm{~mm} /$ year. The NW-SE striking fault has recorded a strike-slip trend of $0.04 \mathrm{~mm} /$ year. In addition, it has been possible to define their precise kinematics. Moreover, different strike-slip mechanisms along two transverse fault systems point to a horizontal stress field orientation. These results confirm the existence of active tectonic structures within central Europe. It is considered that the methodology described here can also be applied in other intracratonic settings where karstic cave systems are present. This would help define potentially seismogenic areas where unambiguous evidence for active faulting is lacking.
\end{abstract}

\section{INTRODUCTION}

The identification and characterization of active fault structures represents a crucial first step in any attempt to define potentially seismogenic areas. In the intracratonic setting of central Europe, such elementary work is often difficult to undertake because active fault movement is slow in comparison to more obviously seismic areas. Accordingly, fault scarps are unlikely to be generated because the overall denudation rate generally exceeds the rate of displacement. The problem is further compounded as the relevant faults are seldom exposed at the surface due to the extensive vegetation coverage (Štěpančíková et al., 2010). As a result, we have instead chosen to specifically examine karstic cave systems for evidence of active faulting. These systems are better able to preserve a record of displacement because the activity is documented within a three dimensional framework unaffected by subsequent erosion. In addition, underground systems are largely shielded from climatic effects such as seasonal massif dilations (Briestenský et al., 2010). It is, therefore, considered that karstic cave systems represent an ideal natural laboratory within which to study active tectonics.

This paper reports on a study of active tectonics undertaken at Driny Cave in the Malé Karpaty Mts, western Slovakia (Fig. 1). The cave is located close to the broadly NE-SW striking Smolenice Fault. This marginal fault is a significant morphostructural feature that separates the Malé Karpaty Mts from the adjacent Blatnianska priehlbina Depression. The cave itself is also of particular importance as it is the only show cave in this part of the country (Slovak Caves Administration, 2006). In addition to the geological and geomorphological mapping of the cave system, three optical-mechanical crack gauges have been installed to record fault displacements. These crack gauges have been regularly monitored since their installation in 2005.

\section{Driny CAVE}

Driny Cave $\left(48^{\circ} 30^{\prime} 01^{\prime \prime} \mathrm{N}, 17^{\circ} 24^{\prime} 27^{\prime \prime} \mathrm{E}\right)$ is located near the town of Smolenice in the district of Trnava, western Slovakia. The cave is situated in the Smolenice Karst, the most significant karst area in the Male Karpaty Mts. The entrance to the cave is located on the western slope of Driny Hill (434 m asl) at an altitude of $399 \mathrm{~m}$ asl (Fig. 2a). It is a network cave consisting of intersecting faultcontrolled fissure passages, sensu Palmer (1991). Driny Cave is a typical fissure cave conditioned by distinct

\footnotetext{
* Corresponding author: briestensky@irsm.cas.cz

${ }^{1}$ Institute of Rock Structure and Mechanics, Academy of Sciences of the Czech Republic, V Holešovičkách 41, 18209 Prague 8, Czech Republic.

${ }^{2}$ Geological Institute, Slovak Academy of Sciences, Dúbravská cesta 9, 84005 Bratislava, Slovakia

${ }^{3}$ Slovak Caves Administration, Hodžova 11, 03101 Liptovský Mikuláš, Slovakia.
} 


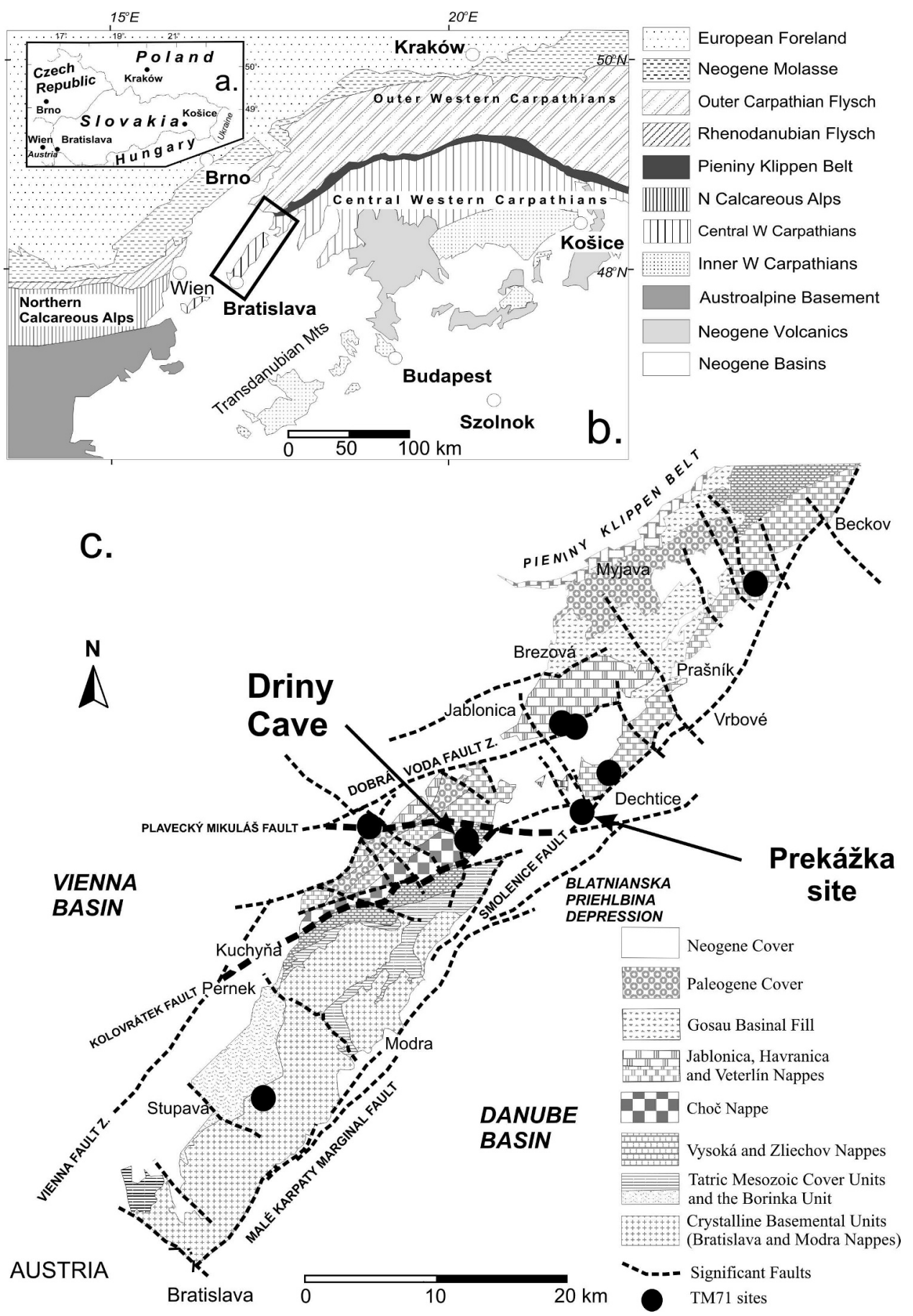

Figure 1. The geology of the Malé Karpaty Mts (modified after: Grabowski et al., 2010; Briestenský and Stemberk, 2008; Briestenský et al., 2010) with the regional network of optical-mechanical crack gauges also marked. A detailed geological map of the study area is presented in Figure 5. Inset: the location of the study area within the context of central Europe.

vertical faults (Fig. 2b). It consists of narrow fissure passages, from one to three meters wide (e.g. Collaborators' Passage, Beňovský's Passage, Passage of Hope), and small halls that are sometimes enlarged at the intersection of fault systems (e.g. Slovak Speleological Society Hall). The cave reaches a length of $680 \mathrm{~m}$ and has a vertical span of $40 \mathrm{~m}$. Discovery Chimney, with a depth of $36 \mathrm{~m}$, descends from the smaller upper entrance ( $430 \mathrm{~m}$ asl) to the intersection between Entrance Passage and Collaborators' Passage (Droppa, 1951, Mitter, 1983, Bella, 2003). The cave has formed in the lower Cretaceous brown-grey chert limestones of the Vysoká Nappe (Michalík et al., 1992). It is thought that the cave originated as a result of corrosion by atmospheric waters seeping along steep failures 
The use of a karstic Cave system in a study of aCtive tectonics: Fault movements Recorded at Driny Cave, Malé Karpaty Mts (Slovakia)
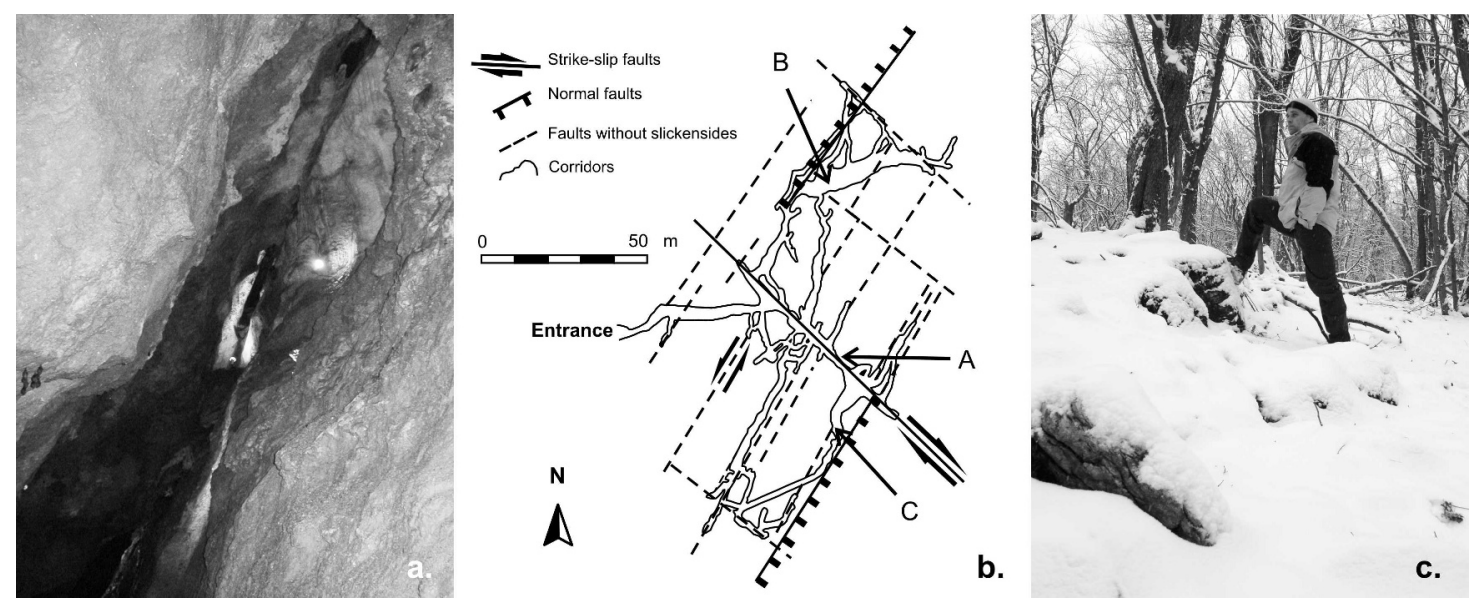

Figure 2. The expression of faults associated with the cave: (a) The entrance to Driny Cave, a fissure passage enlarged by corrosion (Photo: P. Bella); (b) A schematic map of the faults crossing Driny Cave (A: Collaborators' Passage; B: Slovak Speleological Society Hall; C: Chimney Passage). The faults are specified by their displacement mechanism; (c) A terrain step directly above 'Chimney Passage' in Driny Cave.

(Droppa, 1951). The upper, usually narrow, parts of many fissures and several vertical chimneys have been enlarged by corrosion in the vadose zone. In addition to the vadose morphological forms, ceiling pockets, blind holes, oval connecting passages, and water level notches are also noted. The ceiling pockets have been produced by mixing corrosion, the blind holes occur on both the ceilings and the walls, and the oval connecting passages join parallel fissure passages. These morphological and genetic features provide evidence for the phreatic and epiphreatic modeling of the cave as a result of the localized flooding of some passages. Such flooding was caused by the accumulation of clay sediments, which led to blockages within the lower parts of the fissure. Several lateral notches have been sculpted by corrosion directly beneath the contact of the clay sediments, with the rock walls acting as subsidiary features in the overall morphology of the cave (Bella, 2006). The cave is richly decorated with speleothems, mainly comprised of flowstone draperies, stalagmites, and stalactites. In addition, the cave contains small flowstone pools supplied with water from percolating rainfall and melting snow. In the proximal part of the cave, at the base of Discovery Chimney, air temperature fluctuates between 5.6 and $8.7^{\circ} \mathrm{C}$. This variability is due to the influence of the terrestrial climate through the open upper entrance (Zelinka, 2000). At the distal end of the cave, air temperature is far more constant and ranges between 7.1 and $7.8^{\circ} \mathrm{C}$.

\section{Tectonic Structures and Faults}

The cave system is located in the Malé Karpaty Mts, adjacent to the Blatnianska priehlbina Depression. These two distinct morphostructural units are separated by the Smolenice Fault (strike: NE-SW, NNE-SSW). This fault represents the southeastern marginal fault of the Malé
Karpaty Mts and has a vertical throw of over $2000 \mathrm{~m}$ (Maglay et al., 2006). In addition, significant structures are associated with the transverse faults of the Malé Karpaty Mts (strike: NW-SE). To the northwest of the cave, the Smolenice Fault intersects the seismically active Vienna Fault, a sinistral strike-slip transfer fault. Locally, this fault is called the Dobrá Voda Fault. The latter transverse fault system is thought to be responsible for dividing the main ridge of the Malé Karpaty Mts into a series of discrete morphostructural blocks during the Quaternary. It has recently been determined that movement on these NW-SE striking faults are dextral strike-slip (Kováč et al., 2002).

The seismically active Smolenice Fault is characterized by frequent earthquakes. The most notable recent event was recorded on $13^{\text {th }}$ March 2006 close to the town of Vrbové, which recorded a magnitude of $\mathrm{M}_{\mathrm{L}}=3.2$ (Briestenský et al., 2007). This earthquake registered significant normal faulting along the marginal Smolenice Fault and demonstrated active subsidence of the Blatnianska priehlbina Depression. The displacements were recorded using an optical-mechanical crack gauge located at Prekážka, to the northeast of Driny Cave (Fig. 3). In total, the period of seismic activity lasted for six months (March-August 2006). During this period, displacement oscillations (i.e. strike-slip movements and vertical shifts) were also registered in Driny Cave (Fig. 10, Site 3). Earthquake magnitudes are usually lower and energy is normally released through smaller, frequent, earthquakes. Therefore, long-term fault trends are dominant here.

\section{Methodology}

The study was instigated after it was noted that significant speleothem damage is associated with fault outcrops within the cave system (Šebela, 2008). A number 


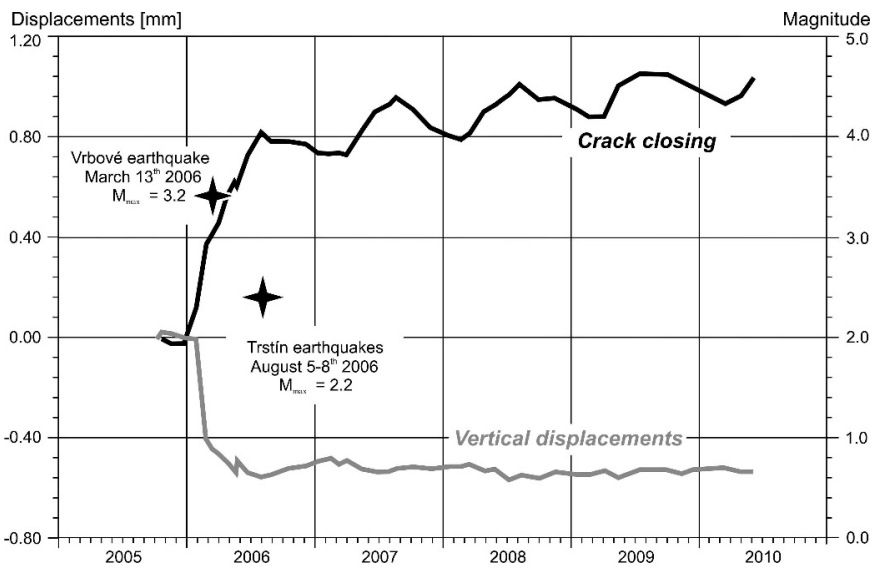

Figure 3. The displacements registered during the most recent phases of seismic activity at Prekážka. Measurements were recorded using an optical-mechanical crack gauge.

of previous studies have shown that such damage is indicative of active tectonics (e.g., Kashima, 1993; Gilli, 2005). Consequently, a range of geological, geomorphological, and in situ displacement data have been collected. The geological data are used to suggest the origins of the cave system, the geomorphological data are used to provide evidence for fault movements, and the in situ displacement data are able to quantify activity at the present day.

\section{Geological and Geomorphological Analyses}

The detailed geological mapping of the study area has previously been published by one of the authors (Michalík et al., 1992). In this study, fault outcrops at the surface were examined for evidence of movement. Within the cave, slickensides were used to determine the sense of fault movement was using the criteria of Petit (1987). The area around Driny Cave was extensively examined for slope failures. These were recorded on base maps using methods adopted from engineering geology (Rybáŕ, 1973). Their precise position and geometry were documented. Within the cave, particular focus was placed on the type and distribution of sinter damage. Where any damage was observed, any clear evidence for the cause was sought.

\section{In Situ Displacement Monitoring}

Displacement monitoring has been undertaken using three optical-mechanical crack gauges, referred to as TM71s. A detailed account of the device has recently been provided in Stemberk et al. (2010). In brief, the relative movement between adjacent fault blocks can be recorded by two identical grid systems when they are mechanically connected (Košt'ák, 1991, 2006) (Fig. 4). It is possible to calculate the three dimensional movement between adjacent blocks with an accuracy of greater of $0.01 \mathrm{~mm} / \mathrm{yr}$, while the resolution for angular deviations is $\pm 1.6 \times 10^{-4}$ grad. A number of studies have demonstrated the value of this type of instrument (e.g., Stemberk \& Štěpančíková,

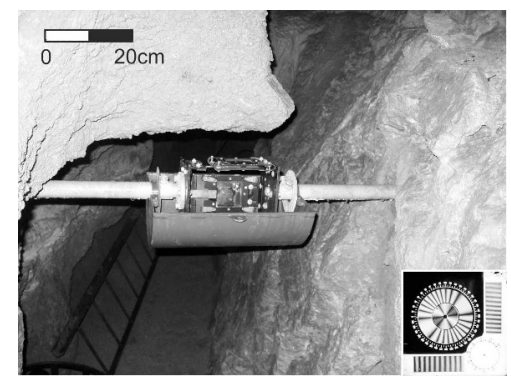

Figure 4. An optical-mechanical crack gauge installed across a significant fault in Bowl Passage. The cover of the instrument (top half removed) shields it against falling rocks. Inset: an example of the moiré (optical-mechanical) effect on the mirror gauge set during a reading.

2003; Stemberk and Košt’ák, 2007; 2008; Briestenský and Stemberk, 2008). As the instruments are sited underground, the faults are largely shielded from climatic effects such as seasonal massif dilations (Briestenský et al., 2010). It is emphasized that the crack gauges do not require electricity or any other power source and, therefore, the device cannot be affected by changes in the electrical or magnetic field.

The crack gauges were installed across the three most significant faults. These were determined by the presence of tiny, fresh, cracks in the speleothems located close to the fault outcrops. The first gauge was placed across a NW-SE striking dextral strike-slip fault $\left(75^{\circ} \rightarrow 040^{\circ}\right.$, i.e. dip $\rightarrow$ dip direction) that forms the main corridor of the cave (Fig. 2b, Site A). The second gauge was placed across a NNE-SSW striking normal fault $\left(70^{\circ} \rightarrow 290^{\circ}\right)$ in Slovak Speleological Society Hall that dips to the WNW (Fig. 2b, Site B). The third gauge was placed across a NNE-SSW striking normal fault $\left(70^{\circ} \rightarrow 110^{\circ}\right)$ close to the Chimney Passage that dips to the ESE (Fig. 2b, Site C). Displacement monitoring began in the fall of 2005, with data recorded at the sites every two weeks since that time.

\section{RESUlts}

\section{Geological and Geomorphological Observations Geological Observations and Slickenside Analysis}

The geological mapping and detailed examination of fault outcrops was undertaken in three cave systems: Driny Cave, Pod zavesenou Cave, and Pod orechom Cave. These analyses demonstrated that the most significant faults to cross the study area are the NW-SE striking dextral strike slip faults. An example of this type of fault is located in 'Collaborators' Passage' of Driny Cave, where there are slickensides preserved on the northeastern cave wall. The sense of previous fault displacements was determined using striations and slickencrysts. It was seen that the displacement mechanism was consistent across all cave corridors 
The use of a karstic Cave system in a study of active tectonics: Fault movements Recorded at Driny Cave, Malé Karpaty Mts (Slovakia)

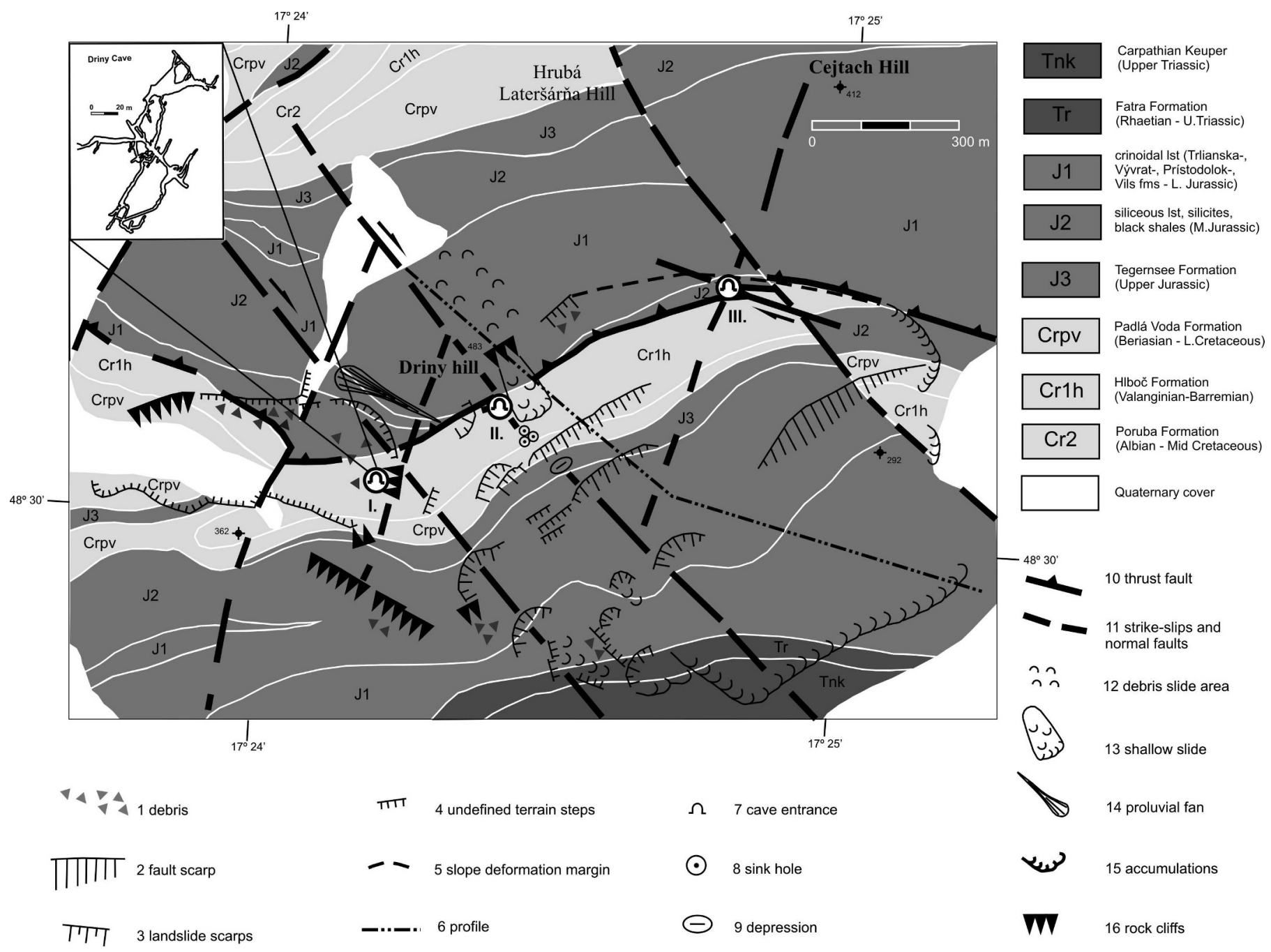

Figure 5. A map of faults and slope failures in the vicinity of Driny Cave (I: Driny Cave; II: Pod zavesenou Cave; III: Pod orechom Cave).

aligned NW-SE. These major fault structures provide the focus for both geomorphological processes at the surface and karstological processes within the cave system. In contrast, the transverse NNE-SSW striking faults show an association with vertical displacements initiated by gravitectonic processes. The striations associated with normal faulting are preserved in both Slovak Speleological Society Hall and Chimney Passage. Due to the larger size of the cave system, these slickensides were only observed in Driny Cave. Unfortunately, many of the slickensides within cave system are concealed by calcite due to the significant sinter production irrespective of strike orientation. Nonetheless, this general scheme appears to be applicable for both the NW-SE dextral strike slip faults and the NNE-SSW transverse faults within Driny Cave.

\section{Geomorphological Observations: Slope Failures}

At the surface, a number of slope failures have been observed (Fig. 5). The most significant of these was an extensive rockslide noted on the southeastern sector of Driny Hill. The deformation has a width of $1,075 \mathrm{~m}$ and extends downslope for more than $200 \mathrm{~m}$. This deformational area is characteristic of a partial scarp formed by a consecutive sequence of slope deformations (Fig. 6). The western part of the rockslide is constrained by a notably deep valley that reflects the presence of a NW-SE striking fault. The fault is not exposed at the surface but has been identified within the cave system. It is located in Collaborators' Passage and controls the development of the gallery in Driny Cave. The eastern part of the rockslide is constrained by a NW-SE dextral striking fault. This fault is also found in the small nearby cave of Pod orechom, which has a total length of $34 \mathrm{~m}$. At the base of the rockslide is a significant accumulation of debris with a frontal wall approximately $20 \mathrm{~m}$ in height. In addition to the significant scarps with a characteristically curved shape, less conspicuous terrain steps also occur here. For example, one is located above Chimney Passage (Fig. 2c). The strike 


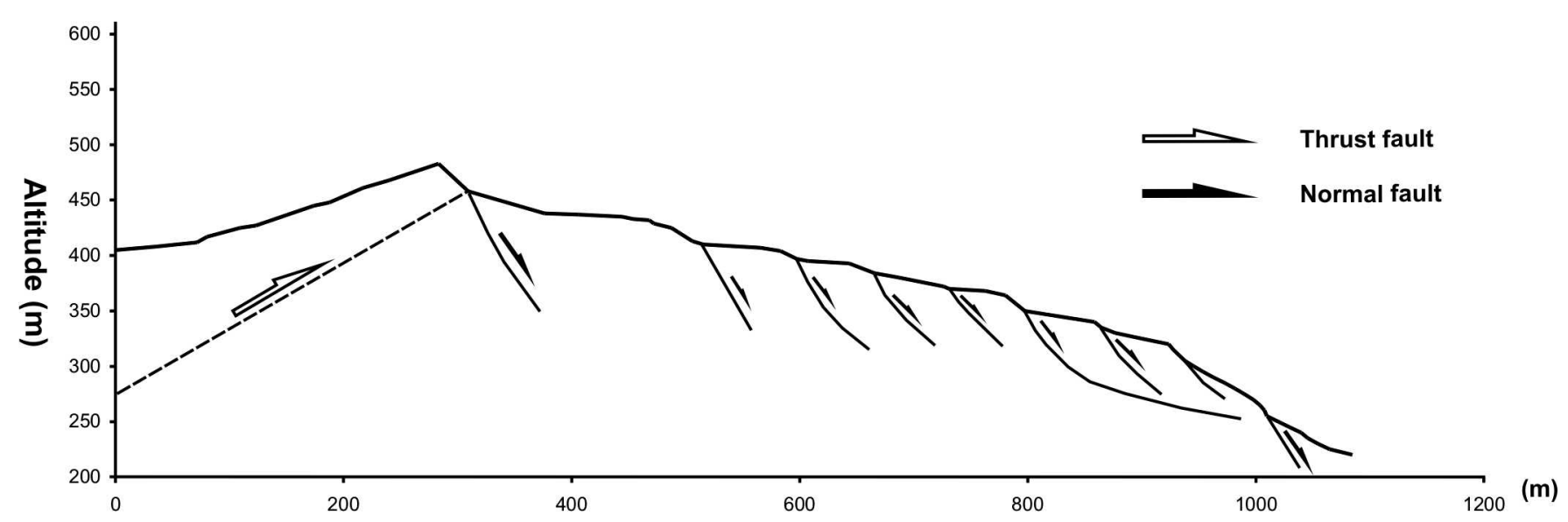

Figure 6. A profile through the slope failures affecting the southeastern side of Driny Hill. The location of the profile is depicted by the line crossing Figure 5 .

and dip direction of the terrain step is identical to that of the normal fault that controls the development of the underlying gallery. The Pod orechom cave has developed along the same fault system as Driny Cave, and also displays evidence for the intersecting NW-SE and NNESSW striking faults.

In addition, the small cave of Pod zavesenou is located within the northern slope of the deformed area. It is a short cave of only 3 meters, which has developed at the intersection of a significant thrust fault and younger NWSE dextral strike slip fault (Fig. 7b). The occurrence of a thrust fault here was previously described by Michalík et al. (1992). According to our studies, the NW-SE fault system forms the dominant system. This controls the overall elevation of Driny Hill, as well as the development of the cave galleries. Furthermore, the southern slope of the deformed area rests upon the active normal faults that form part of the Smolenice Marginal Fault System (SMFS). This system forms the northwestern boundary between the Malé
Karpaty Mts and the Blatnianska priehlbina Depression. Its recent activity was described earlier. Therefore, it can clearly be seen that the development of the slope deformation on the southeastern side of Driny Hill was influenced by occurrence of the fault intersection.

The surveyed valley in front of the entrance to Driny Cave, on the western side of Driny Hill, does not visibly reflect this slope deformation origin. It is possible to only find significant amphitheatre cliffs with debris and terrain steps. In contrast, normal fault slickensides were found in the Slovak Speleological Society Hall during the surveying of Driny Cave. The dip direction of this structure is orientated towards the valley. Recent activity has been recorded by a crack gauge. The fault is actually located in the scarp of the slope deformation. Dosedla (1974) and Bella (2006) both supposed that possible gravitational slope block movements occurred close to the entrance of the cave. The motion of the blocks is documented by open failures on surface (Fig. 8).
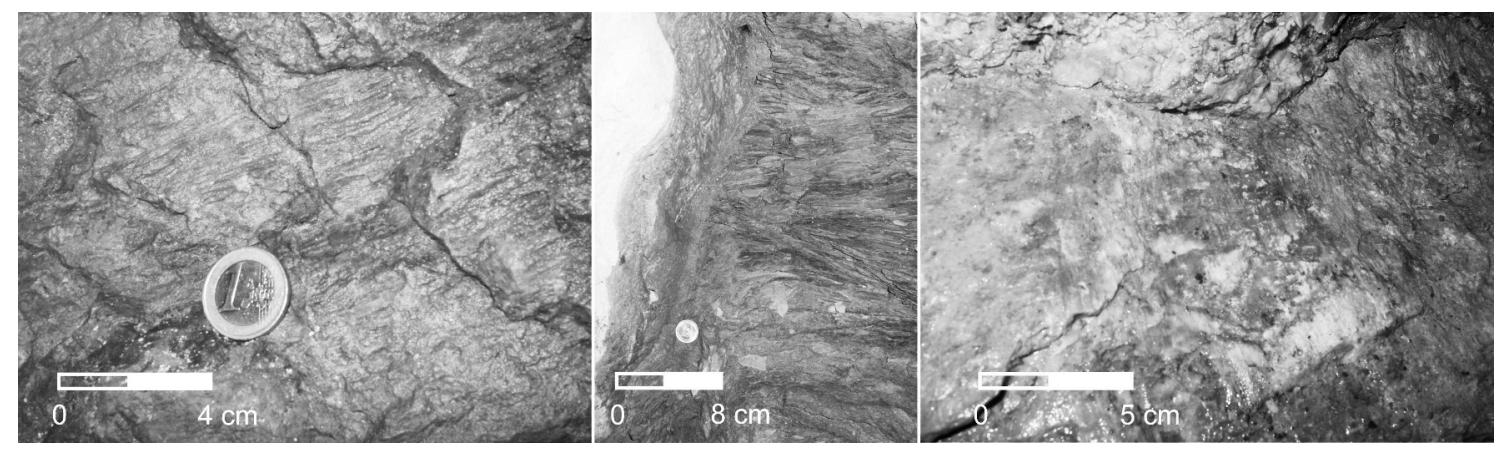

Figure 7. Faults with slickensides in nearby caves: (a) A slickenside on a NW-SE striking fault. This fault creates the passage of Pod orechom Cave; (b) A thrust fault, on the right hand side, cut by younger dextral strike-slip fault, on the left hand side, in Pod zavesenou Cave; (c) Slickenside on the fault plane below Site No. 1 in Driny Cave. The fracture steps, striations, and slickencrysts define the previous normal faulting along the fault plane. 


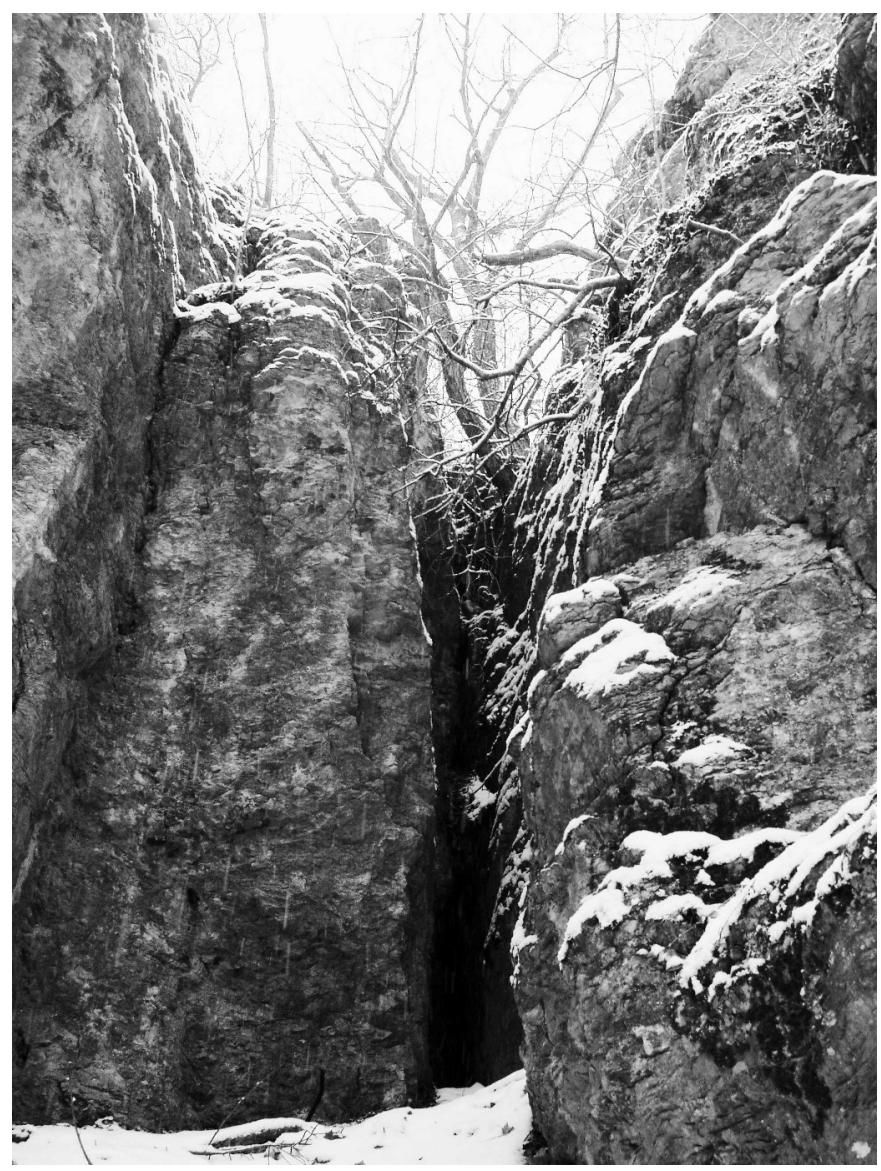

Figure 8. An amphitheatre cliff with an open crack in vicinity of the entrance to Driny Cave. This crack is indicative of block movements in the scarp area.

\section{Geomorphological Observations: Speleothem Damage}

Within the cave, numerous broken or tilted stalagmites have been identified. These are usually assumed to reflect previous fault activity or sensitivity of the underground spaces to nearby earthquakes of significant power
(Fig. 9b). The freshly broken speleothems follow the fault strike in Driny Cave showing recent block displacements. Due to the fact that fresh cracks follow the blocks contacts and are found on the ceiling without any significant sinter crust or decoration (Fig. 9a), we could exclude all other principal causes recognized for speleothem breakage such as instability of the ground, collapse of the cave floor, water flow, ice, and anthropogenic impacts.

\section{In Situ Displacement Monitoring}

Over the past five years, the behavior of the faults has shown significant patterns. The NW-SE striking fault in 'Collaborators' Passage' (Driny 3) has displayed subsidence of the northeastern block by $0.03 \mathrm{~mm} / \mathrm{yr}$ and dextral strike-slip displacement trend of $0.04 \mathrm{~mm} / \mathrm{yr}$ (Fig. 10) The dextral strike-slip results are in full accordance with previous geological ideas regarding the mechanism of the transverse Malé Karpaty strike-slip fault displacements (Kováč et al., 2002). In addition, the observed sense of displacement reflects a continuation of the horizontal dextral shift previously noted on slickensides in the Collaborators' Passage. Furthermore, minor seasonal massif dilations have been noted at Driny 3. The crack opening component is associated with a peak-to-peak amplitude of $0.05 \mathrm{~mm}$ (Briestenský et al., 2010) and vertical seasonal variation is associated with a peak-to-peak amplitude of $0.07 \mathrm{~mm}$. Such changes were not identified at the two other sites (Driny 1 and Driny 2).

The optical-mechanical crack gauges have also provided further understanding of the rock massif behavior. In contrast to the dextral strike-slips recorded along the NWSE striking fault, sinistral strike-slip displacements have been recorded along the NNE-SSW directed faults (Fig. 10, Driny 1). The recognized sense of displacement reflects a continuation of the horizontal sinistral shift previously noted on a slickenside in the western part of the cave (Fig. 2b). This fault mechanism is due to the fact that the local stress field compression is thought to have recently been oriented in a NNW-SSE direction (or in
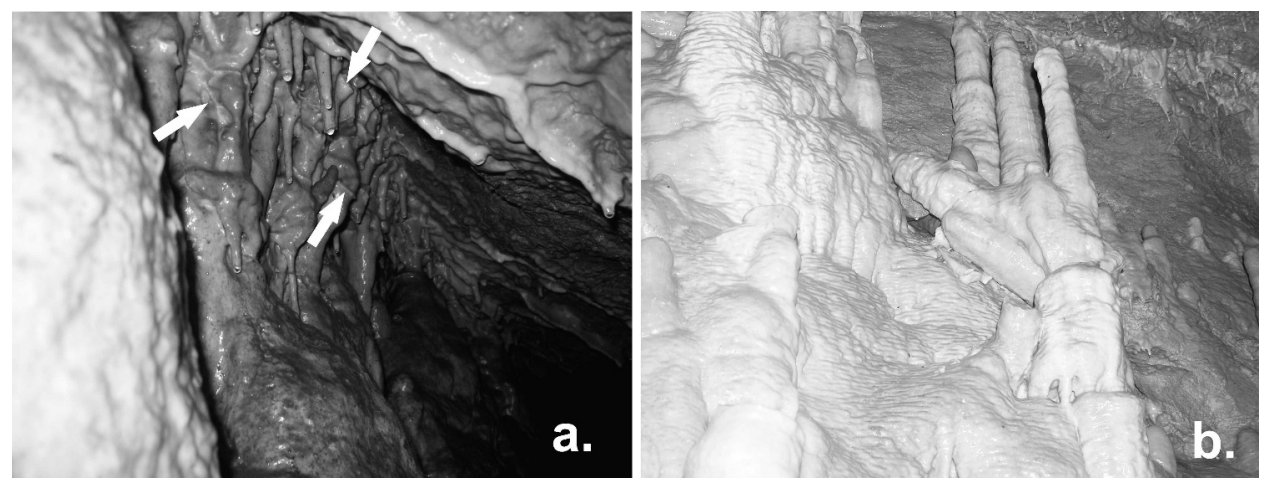

Figure 9. Damaged sinter decoration: (a) tiny cracks freshly healed by white sinter occur along the block contacts and affect ceiling sinter decoration across the entire cave system. The picture is taken close to Site 3; (b) a broken stalagmite in Driny Cave. 

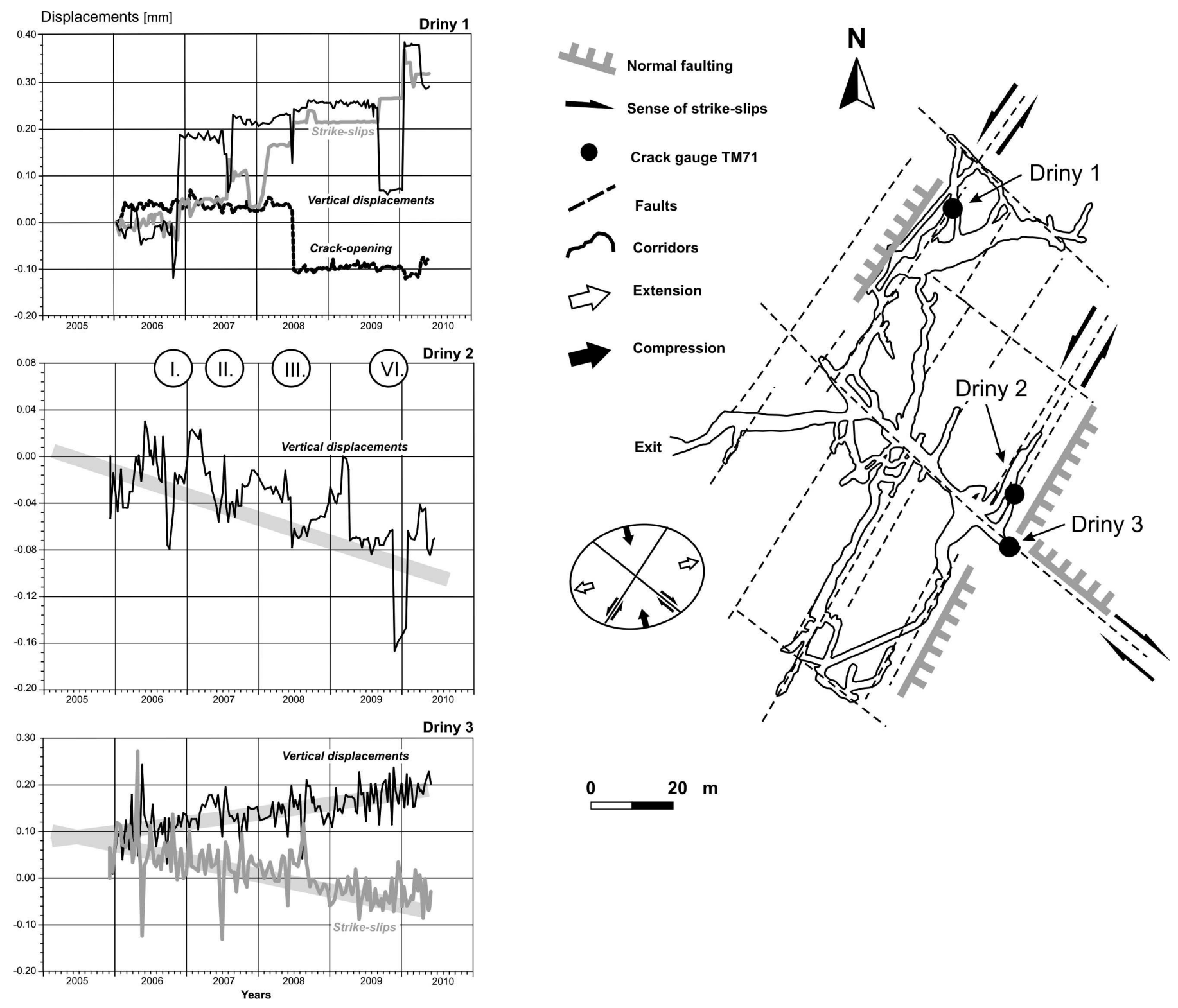

Figure 10. Significant displacements registered at the monitored sites (left) and the sense of recent horizontal strike-slip and normal fault displacements along the observed faults in Driny Cave (right). The black dots show the location of the crack gauges.

close declination) with extension in an ENE-WSW direction (Fig. 10). The sense of regional 2D deformation ellipse model is derived from McClay (1987). The sinistral strike-slip displacements are consistent with the interpreted displacement mechanism along the Smolenice Fault, in addition to the other NE-SW and N-S striking faults in the Malé Karpaty Mts (Kováč et al., 2002).

The vertical displacement recorded along the fault in Slovak Speleological Society Hall (Fig. 10, Driny 1) shows significant subsidence of the WWN block. This is in full accordance with the sense of fault displacement observed on the slickensides noted at the site. The active vertical block movements support our idea of a subsidence- related origin for the valley in front of the entrance to Driny Cave. The subsidence of the WWN block is usually preceded by subsidence of the opposite EES block. This refers not only to one block shift, but also displacements in the block zone tend to subside in a westerly-dipping direction. The two block displacements are displayed as oscillations in the graph (Fig. 10, Driny 1). The most significant horizontal opening occurred at beginning of July 2008. The total shift of the WWN block reached $0.125 \mathrm{~mm}$ (Fig. 10, Driny 1).

These subsidence trends caused by block fault displacements are seen in the measurements recorded at Site 2 (Fig. 10, Driny 2). The total vertical trend, with a SE dip 
The use of a karstic Cave system in a study of aCtive tectonics: Fault movements Recorded at Driny Cave, Malé Karpaty Mts (Slovakia)

direction, is $0.03 \mathrm{~mm} / \mathrm{yr}$. This vertical displacement is associated with the vast slope deformation above the village of Smolenice, which has affected the southeastern side of Driny Hill. These displacements are still active, as shown by the continuous formation of the slope deformation on the western side of Driny Hill. The most visible vertical displacements oscillations (two block movements) occurred at the same time at both Sites 1 and 2. Four periods of significant vertical displacement have been recorded (Fig. 10) along the NNE-SSW striking fault system, without any relationship to peak-to-peak seasonal amplitude. This demonstrates the sensitivity of the whole gravitectonic system to stress changes within the rock massif.

\section{DisCUSSION}

\section{Summary of Results}

An important relationship between surface phenomena and faults cutting the cave has been identified. The geomorphological investigation of the adjacent area has shown significant slope deformation on the southeastern and western sides of Driny Hill. This deformation appears to reflect the underlying influence of two fault systems, the Smolenice Fault System and the transverse Malé Karpaty Mts System. These fault systems are now known to have also influenced the development of passages in Driny Cave as the cave system follows the strike of these two faults. It is clear that fresh sinter breakage in the cave is due to active block fault movement. In addition, slickensides preserved within the cave have allowed us to determine fault mechanisms. The sinter damage and slickensides have been used to help select appropriate sites for fault displacement monitoring. Three optical-mechanical crack gauges have been regularly monitored for the past five years. These data reveal continuing displacement activity characterized by dextral strike-slip movements along NW-SE striking faults and sinistral strike-slip movements along NNE-SSW striking faults. From this, it is deduced that the present stress field is subject to compression in a NNW-SSE direction. The vertical displacements observed along the faults demonstrate ongoing subsidence on the southeastern and western sides of Driny Hill. During the monitoring period, a significant period of earthquake tremors occurred from spring to fall 2006. At this time, all of the monitored structures in Driny Cave were affected by sudden reversals in their sense of movement (or displacement oscillations) with significant vertical and strike-slip displacements recorded. In total, four displacement oscillation events can be recognized. These appear to have been initiated along faults within the Blatnianska priehlbina Depression. It is proposed that these events reflect either higher levels of seismic activity or active basin development. Either way, it is clear that tectonic activity in the nearby Blatnianska priehlbina Depression has an influence on the fault displacements recorded within Driny Hill.

\section{The Advantages of Using Closely Spaced Crack Gauges}

At the beginning of 2002, a monitoring network of opticalmechanical crack gauges (EU-TecNet) was established across central Europe (Stemberk et al., 2003). The network incorporates the most significant tectonic structures of the Bohemian Massif and Western Carpathians. A number of recent studies have shown that this monitoring net is able to record aseismic fault displacements with a high degree of precision (e.g., Šebela et al., 2005; Briestenský et al., 2007; 2010; Štěpančíková et al., 2008). Unfortunately due to the considerable distances between monitoring sites, understanding the precise kinematics can be complex. For example, one of the most significant problems encountered during such measurements relates to the interpretation of sudden reversals in the sense of movement. It is frequently unclear as to whether one fault block remains entirely stable while the adjacent block is active or whether there is motion on both blocks. Therefore, the three monitoring crack gauges installed at Driny Cave provide a unique opportunity to examine displacement along adjacent fault systems. From these, it has been possible to define the precise kinematics of the fault movements and thereby constraining the underlying mechanism. These results also help to define the total amount of displacement along the fault. In addition, the closely spaced crack gauges are able to reveal recent changes in the local stress field orientation (Briestenský and Stemberk, 2008).

\section{The Advantages of Using Karstic Cave Systems}

To counter the problems associated with identifying active tectonic structures in intracratonic settings, we chose to specifically examine karstic cave systems for evidence of active faulting. These systems are better able to preserve a record of displacement because the activity is recorded within a three dimensional framework unaffected by subsequent erosion. In particular, it is suggested that karstic cave systems have four main advantages. First, fresh sinter breakage is frequently due to active block fault movements. In this study, the subsequent measurements recorded in the cave have corroborated this idea. Second, the slickensides preserved within the cave have allowed us to determine fault mechanisms. Third, the geometry of the individual passages within the cave system is ideal for the installation of opticalmechanical crack gauges. Fourth, there is no significant correlation between fault displacements and precipitation. It should be noted that a minor correlation between fault displacement and seasonal massif dilation can be indentified but this does not affect the overall trend. The influence of climate decreases with depth below the surface. This is discussed further in Briestenský et al. (2010).

\section{Conclusions}

This study has successfully integrated geological, geomorphological, and in situ displacement data recorded around and within a karstic cave system. These results 
demonstrate the existence of active tectonic structures within the intracratonic setting of central Europe in the junction zone between Eastern Alps and Western Carpathians. In particular:

- The cave system has developed along significant fault structures, which can be seen from geological mapping and slickenside analyses.

- The possibility of ongoing faulting and block movements were suggested by the considerable number of slope failures on hillsides above the cave and the numerous fresh speleothem breaks observed within the cave.

- The notion of active faulting and block movements has been confirmed and quantified using three opticalmechanical crack gauges.

- It has been possible to define the precise fault kinematics. Different strike-slip mechanisms along two transverse fault systems point to a horizontal stress field orientation.

It is considered that the methodology described here can also be applied in other intracratonic settings where karstic cave systems are present. This would help define potentially seismogenic areas where unambiguous evidence for active faulting is lacking.

\section{ACKNOWLedGements}

All financial support is gratefully acknowledged. The study was financed by the IRSM ASCR (Code A: VOZ30460519), the Czech Science Foundation (Project Nos. 205/05/2770; 205/06/1828 \& 205/09/2024), the Czech Ministry of Education, Youth, and Physical Culture (Project COST OC 625.10), and VEGA 0196. Figure 9(10) provided by P. Zvonar.

\section{REFERENCES}

Bella, P., 2003, Slovensko sprístupnené jaskyne [Slovakia show caves]: Slovak Caves Administration, Liptovský Mikuláš, p. 38-41.

Bella, P., 2006, Príspevok k morfológii a genéze jaskyne Driny [A contribution to the morphology and genesis of Driny Cave]: Aragonit, v. 11, p. 4-9

Briestenský, M., Stemberk, J., and Petro, L., 2007, Displacements registered around March $13^{\text {th }} 2006$ Vrbové earthquake, $\mathrm{M}=3.2$ (Western Carpathians): Geologica Carpathica, v. 58, p. 487-493.

Briestenský, M., and Stemberk, J., 2008, Monitoring mikropohybov v jaskyniach Západného Slovenska [Monitoring microdisplacements in the caves of western Slovakia]: Slovenský kras, v. 46, p. 77-83.

Briestenský, M., Košt'ák, B., Stemberk, J., Petro, L., Vozár, J., and Fojtíková, L., 2010, Active tectonic fault microdisplacement analyses: a comparison of results from surface and underground monitoring in western Slovakia: Acta Geodynamica et Geomaterialia, v. 7, p. 387-397.

Droppa, A., 1951, Smolenický kras v Malých Karpatoch [Smolenice Karst in the Small Carpathians]: Zemepisný sborník [Geographical Proceedings], v. 3, p. 7-52.

Dosedla, J., 1974, Příspěvek k poznání krasu v Malých Karpatech [Contribution to the knowledge of karst in the Small Carpathians]: Sborník Československé Společnosti Zeměpisné [Proceedings of Czechoslovak Geographical Society], v. 52, p. 88-91.

Gilli, E., 2005, Review on the use of natural cave speleothems as palaeoseismic or neotectonics indicators: Comptes Rendus Geosciences, v. 337, p. 1208-1215.
Grabowski, J., Michalík, J., Pszczólkowski, A., and Lintnerová, O., 2010, Magneto- and isotope stratigraphy around the Jurassic/Cretaceous boundary in the Vysoká Unit (Malé Karpaty Mountains, Slovakia): correlations and tectonic implications: Geologica Carpathica, v. 4, (in press).

Kashima, N., 1993, Fracture of speleothems in Hoshino-no-ana Cave, Minami-Daito Island, Okinawa Prefecture, Southwest Japan: Journal of the Speleological Society of Japan, v. 18, p. 33-41.

Košt'ák, B., 1991, Combined indicator using moiré technique in Sorum, G. Field Measurements in Geomechanics, Rotterdam, Balkema, p. 53-60.

Košt'ák, B., 2006, Deformation effects in rock massifs and their long-term monitoring: Quarterly Journal of Engineering Geology and Hydrogeology, v. 39, p. 249-258.

Kováč, M., Bielik, M., Hók, J., Kronome, B., Labák, P., Moczo, P., Plašienka, D., Šefara, J., and Šujan, M., 2002, Seismic activity and neotectonic evolution of the Western Carpathians (Slovakia): EGU Stephen Mueller Special Publication, Series 3, p. 167-184.

Maglay, J., editor, 2006, Geological Map of the Danube LowlandTrnavská Pahorkatina Upland: State Geological Institute of Dionýz Štúr, scale 1:50 000, 1 sheet.

McClay, K.R., 1987, The Mapping of Geological Structures: Milton Keynes, Open University Press, $161 \mathrm{p}$.

Michalík, J., Reháková, D., and Marko, F., 1992, Stratigrafia a tektonika spodnokriedovej vápencovej sekvencie v profile jaskyne Driny (Vysoká jednotka, Malé Karpaty Mts) [Stratigraphy and tectonics of lower Cretaceous limestone sequence in a profile from Driny Cave (Vysocká Unit, Small Carpathians)]: Mineralia Slovaca, v. 24, p. 235-243.

Mitter, P., 1983, Geomorfologická rajonizácia krasu Malých Karpát [Geomorphological zoning of the karst Small Carpathians]: Slovenský kras, v. 21, p. 3-34.

Palmer, A.N., 1991, Origin and morphology of limestone caves: GSA Bulletin, v. 103, p. 1-21.

Petit, J.P., 1987, Criteria for the sense of movement on the fault surfaces in brittle rocks: Journal of Structural Geology, v. 9, p. 585-608.

Rybáŕ, J., 1973, Representation of Landslides in Engineering Geological Maps: Landslide, v. 1, p. 15-21.

Slovak Caves Administration, 2006, Driny Cave: www.ssj.sk/jaskyne/ spristupnene/driny [accessed: 06.26.2010].

Šebela, S., 2008, Broken speleothemes as indicator of tectonic movements: Acta Carsologica, v. 37, p. 52-62.

Šebela, S., Gosar, A., Košt'ák, B., and Stemberk, J., 2005, Monitoring of active faults in Slovenia: Acta Geodynamica et Geomaterialia, v. 1, p. $45-57$.

Stemberk, J., and Košt'ák, B., 2007, 3-D trend of aseismic creep along active faults in western part of the Gulf of Corinth, Greece: Acta Geodynamica et Geomaterialia, v. 4, p. 53-65.

Stemberk, J., and Košt'ák, B., 2008, Recent tectonic microdisplacements registered in Bedřichov Tunnel "A" in the Jizerské Hory Mts (N Bohemia): Acta Geodynamica et Geomaterialia, v. 5, p. 377-388.

Stemberk, J., Košt'ák, B., and Cacoń, S., 2010, A tectonic pressure pulse and increased geodynamic activity recorded from the long-term monitoring of faults in Europe: Tectonophysics, v. 487, p. 1-12.

Stemberk, J., Košt'ák, B., and Vilímek, V., 2003, 3-D monitoring of active tectonic structures: Journal of Geodynamics, v. 36, p. 103-112.

Stemberk, J., and Štěpančíková, P., 2003, Tectonic setting and monitoring of recent tectonic deformation in the Rychlebské Hory Mts: Acta Montana, v. 24, p. 153-161.

Štěpančíková, P., Stemberk, J., Vilímek, V., and Košt’ák, B., 2008, Neotectonic development of drainage networks in the East Sudeten Mountains and monitoring of recent fault displacements (Czech Republic): Geomorphology, v. 102, p. 68-80.

Štěpančíková, P., Hók, J., Nývlt, D., Dohnal, J., Sýkorová, I., and Stemberk, J., 2010, Active tectonics research using trenching technique on the south-eastern section of the Sudetic Marginal Fault (NE Bohemian Massif, central Europe): Tectonophysics, v. 485, p. 269-282.

Zelinka, J., 2000, Speleoklimatický monitoring jaskyne Driny [Speleoclimatic monitoring in Driny Cave] in Proceedings, Výskum, využivanie a ochrana jaskýň [Research, Use, and Conservation of Caves], $2^{\text {nd }}$, Liptovský Mikuláš: Liptovský Mikuláš, Slovak Caves Administration, p. 168-179. 